\title{
Voice Characteristics of Some Sheep: Utilization to Estimation of Genetic Distance
}

\author{
Handiwirawan $\mathrm{E}^{1}$, Noor $\mathrm{RR}^{2}$, Sumantri $\mathrm{C}^{2}$, Subandriyo ${ }^{3}$ \\ ${ }^{1}$ Indonesian Center for Animal Research and Development \\ ${ }^{2}$ Department of Production Science and Animal Husbandry Technology, Faculty of Animal Science, Bogor Agricultural University \\ ${ }^{3}$ Indonesian Research Institute for Animal Production, Bogor \\ E-mail: eh_wirawan@yahoo.com
}

(received 21-09-2015; revised 27-11-2016; accepted 11-12-2016)

\begin{abstract}
ABSTRAK
Handiwirawan E, Noor RR, Sumantri C, Subandriyo. 2015. Karakteristik suara beberapa rumpun domba dan pemanfaatannya untuk pendugaan jarak genetik. Indones J Anim Vet Sci. 20(4): 257-267. DOI: http://dx.doi.org/10.14334/jitv.v20i4.1274

Analisa suara telah dilakukan dalam berbagai kegunaan diantaranya identifikasi dan pembedaan spesies serta penyusunan taksonomi pada beberapa spesies hewan karena beberapa kelebihan, diantaranya tidak perlu menangkap atau terlalu dekat dengan subjek yang diamati. Analisa suara yang digunakan untuk pembedaan dan pendugaan jarak genetik rumpun domba belum pernah dilaporkan. Penelitian ini dilakukan untuk mempelajari karakter suara beberapa rumpun domba dan kemungkinannya dipergunakan sebagai alat penduga jarak genetik antar rumpun domba. Penelitian dilakukan di Kandang Percobaan Domba, Balai Penelitian Ternak, Bogor. Sebanyak 20 ekor dari lima rumpun domba dewasa (St. Croix cross/SC, Barbados Black Belly cross/BC, Lokal Garut/LG, Komposit Garut/KG dan Komposit Sumatera/KS) digunakan dalam penelitian ini. Suara panggilan (call sound) direkam menggunakan alat digital voice recorder. Analisa suara dilakukan dengan Software Raven Pro 1.3 for Windows untuk menghitung sebanyak 24 peubah suara. Analisa ragam dari setiap peubah suara dilakukan menggunakan PROC GLM dari software SAS Ver. 9,0. PROC CANDISC digunakan untuk analisa diskriminan kanonikal dan selanjutnya PROC TREE digunakan untuk membangun dendogram. Hasil analisa suara menunjukkan bahwa di antara kelima rumpun domba terdapat variasi dalam peubah amplitudo, energi, daya dan frekuensi. Berdasarkan plotting kanonikal, domba LG, KS dan BC merupakan rumpun domba yang berbeda kelompok. Dari hasil penelitian disimpulkan bahwa peubah-peubah karakteristik suara yang dapat digunakan sebagai pembeda rumpun domba adalah frekuensi kuartil ketiga, frekuensi tengah, frekuensi maksimum dan waktu frekuensi kuartil pertama. Dendogram yang dibangun menempatkan rumpun domba KG pada kelompok yang kurang akurat. Metode pendugaan jarak genetik dengan menggunakan data karakteristik suara mempunyai peluang untuk diaplikasikan.
\end{abstract}

Kata Kunci: Karakteristik, Suara Panggilan, Pembedaan, Jarak Genetik, Domba

\section{ABSTRACT}

Handiwirawan E, Noor RR, Sumantri C, Subandriyo. 2015. Voice characteristics of some sheep: Utilization to estimation of genetic distance. Indones J Anim Vet Sci. 20(4): 257-267. DOI: http://dx.doi.org/10.14334/jitv.v20i4.1274

Sound analysis has been carried out in various activities including identification and differentiation of species as well as the preparation of the taxonomy of some animals' species because of several advantages, including no need to capture or too close to the subject observed. Analysis of voice used to differentiate and to estimate of breeds' sheep genetic distance has not been reported. This research was conducted to study the character of a few breeds' sheep sound and likely to be used as a predictor of genetic distance between breeds of sheep. The study was conducted in the Animal House at Indonesian Research Institute for Animal Production, Bogor. A total of 20 head adult of five sheeps (St. Croix cross/SC, Barbados Black Belly cross/BC, Local Garut/LG, Composite Garut/KG and Composites Sumatra/KS) used in this study. Call sound recorded using a digital voice recorder. Sound analysis performed by Raven Software Pro 1.3 for Windows to count as many as 24 variables sound. Analysis of variance of each variable sound was performed using PROC GLM of SAS software Ver. 9.0. It used PROC CANDISC for canonical discriminant analysis and then PROC TREE to build a dendogram. The results showed that there were variations in amplitude, energy, power and frequency variables among the five breeds of sheep. By plotting canonical, LG, KS and BC sheep were from a different group. It was concluded that the sound characteristics variables which can be used as a differentiator breeds of sheep were the third quartile frequency, center frequency, maximum frequency and the first quartile time. Dendogram showed that KG sheep was in the less accurate group. Genetic distance estimation method using voice characteristic data may be applied on sheep.

Key Words: Characteristics, Call Voice, Differentiation, Genetic Distance, Sheep 


\section{INTRODUCTION}

In the context of animal behavior, communication is the sharing of information between two or more individual animals (Scott 2005). All animals communicate with a combination of visual, auditory and olfactory/chemical transmission and through physical contact. Communication is critical in the survival of individuals and species because it has a relationship with the protection (Suzuki 2014), reproduction, and an introduction of mother-to-child (Sèbe et al. 2010). Voice is one important way of communicating among many animal species.

Vocalization in mammals consists of a number of different call types (Fitch et al. 2002). In a voice animal contains some of information about the animal, including an identity (Price et al. 2009), social ranking (Vannoni \& McElligott 2008), age, sex and size (Hall et al. 2013; Ey et al. 2007).

It has also been understood that the behavior of a cow may be used as an indicator of mental and physiological conditions (Manteuffell et al. 2004) until the level of stress to assess the status of animal welfare. Engeldal et al. (2013) have reported that social isolation on several breeds of sheep led to changes in the characteristics of the resulting vocalization, as well as in goats (Siebert et al. 2011). Voice analysis have potential as a tool monitors the welfare of cows (Meen et al. 2015), as well as observation of voice activity in the water on the whale that "caged" was an effective method to monitor the level of stress (Castellote \& Fossa 2006).

Some previous researchers have reported the use of voice analysis in a variety of purpose for identification, differentiation of species and taxonomic. Ruppell (2010) have studied the diversity of voices two Gibbon population in Vietnam and Laos and assess the taxonomic relationships among both populations. The results of sound analysis conducted Gogala \& Trilar (2004) has proposed changes to the taxonomy of crickets under consideration behavior vocalization. In birds, chirping voice difference was most reliable criterion in the differentiation of species of birds (Mahler \& Gil 2009).

Voice analysis has been utilized in supporting the genetic and morphological data to reconstruct the evolutionary history of species of Woodpecker birds (Benz \& Robbins 2011). Identification and differentiation of bird species are separated geographically by songbird have been successfully conducted and reported by Ohya (2004) in bird of Tibicen in Japan, Mena \& Mora (2011) in bird of Cuban Toby (Todus multicolor) in Cuba, Lovell \& Lein (2013) in bird of Alder flycatchers (Empidonax alnorum). Squirrels difficult to distinguish by its morphology, Esser et al. (2008) have reported that the voice analysis successfully used to identify and distinguish the species of squirrel. Ranft (2004) suggested that between the uses of voice analysis is for the description, comparison and analysis of voice; identification of species, populations and individuals; taxonomy and systematics; luring and trapping, and prevention of pest.

The use of voice analysis in various scientific activities has several advantages, including one noninvasive method that does not need to catch or get too close to the subject observed. With the current recording equipment, data recording allows to be obtained in which the subject is not visible or invisible but it is not clear, for example, because the subject is hidden in the forest or on observations done at night for nocturnal animals (Burton \& Nietsch 2010). To facilitate the work, now the identification of the species is possible to do automatically (Chesmore 2004).

Analysis of voice used for the differentiation and genetic distance estimation breeds of sheep has not been reported. Voice change due to hybridization to understand the processes that lead to speciation species have been studied by Dere'gnaucourt (2010) in Quail. Studies conducted Rheindt et al. (2008) showed that based on DNA evidence, vocalizations may be a better indicator for taxonomy than a feather pattern. Based on previous research on these birds, the voice characterization studies conducted in several breeds of sheep that are genetically have a relationship to predict of genetic distance.

This research was conducted to study the voice character of a few breeds of sheep and likely used as a tool the genetic distance between breeds of sheep. The results are expected to be used as an alternative in the estimation of genetic distances in sheep.

\section{MATERIAL AND METHOD}

The study was conducted in two Cage Experiment Sheep in Cilebut and Bogor at Indonesian Research Institute for Animal Production. The equipment used was a digital voice recorder which records the sound of sheep in the MP3 file format. Sheep used in the research was the adult sheep (aged 2-9 years) from five breeds of sheep namely St. Croix cross (SC, 50\% Local Sumatra 50\% St. Croix), Barbados Black Belly cross (BC, 50\% Local Sumatra 50\% Barbados Black Belly), Local Garut (LG), Composite Garut (KG, 50\% Local Garut 25\% St. Croix 25\% Moulton Charolais) and Composite Sumatra (KS, 50\% Local Sumatra 25\% St. Croix 25\% Barbados Black Belly). The amount of each breeds of sheep used in this study were 20 heads (5 males and 15 females in status after weaning).

Each of the sampled sheep separated from sheep group to another empty cage to stimulate the sheep give a call voice. The duration of observation to each sheep 
varied until collected about 5-10 record voice calls. Before further analysis, the voice sample was cleaned from noise, hiss and the voices that are not desired (such as footsteps, the sound of other sheep, etc.), using Wavepad Sound Editor software Ver. 4.28. Sheep voice samples were mixed with the other sheep was not used in the analysis. The average of three voice recording from each head then analyzed further. Sheep voice analysis done with Sound Analysis Software Raven Pro 1.3 for Windows; software created by the Cornell Laboratory of Ornithology; downloaded and purchased from the website http://birds.cornell.edu/ The voice of sheep from the five breeds was translated by Raven 1.3 Pro software in the form of spectrogram and waveform.

Voice analysis by Raven Software 1.3 Pro (Charif et al. 2008), describes the voice characteristics of the each of five breeds. Variables were measured:

1. Delta Time (DELTIME) $=$ Difference between begin time and end time for the selection (Units: seconds).

2. Length of Waveform (LWAVE) $=$ Number of frames contained in a selection. For waveform views, the number of frames equals the number of samples in a single channel (Units: frames).

3. Maximum Amplitude (MAXAMP) = Maximum of all the sample values in the selection (Units: dimensionless sample values).

4. Maximum Amplitude Time $($ MAXAMPT $)=$ First time in the selection at which a sample with amplitude equal to max amplitude occurs (Units: seconds).

5. Minimum Amplitude (MINAMP) = Minimum of all sample values in the selection (Units: dimensionless sample values).

6. Minimum Amplitude Time $($ MINAMPT $)=$ First time in the selection at which a sample with amplitude equal to min amplitude occurs (units: seconds)

7. Peak Amplitude (PAMP) $=$ Greater of the absolute values of max amplitude and min amplitude (Units: dimensionless).

8. Peak Amplitude Time $($ PAMPT $)=$ First time in the selection at which a sample with amplitude equal to Peak Amplitude occurs (Units: seconds).

9. RMS Amplitude (RMSAMP) = Root-mean-square amplitude of the selected part of the signal (Units: dimensionless sample units).

10. 1st Quartile Frequency $($ Q1FREQ $)=$ Frequency that divides the selection into two frequency intervals containing $25 \%$ and $75 \%$ of the energy in the selection (Units: Hz).

11.1st Quartile Time (Q1TIME) = Point in time that divides the selection into two time intervals containing $25 \%$ and $75 \%$ of the energy in the selection (Units: seconds). 12.3rd Quartile Frequency $(\mathrm{Q} 3 \mathrm{FREQ})=$ Frequency that divides the selection into two frequency intervals containing $75 \%$ and $25 \%$ of the energy in the selection (Units: $\mathrm{Hz}$ ).

13.3rd Quartile Time (Q3TIME) $=$ Point in time that divides the selection into two time intervals containing $75 \%$ and $25 \%$ of the energy in the selection (Units: seconds).

14. Average Power $($ AVGPOW $)=$ Value of the power spectrum averaged over the frequency extends of the selection (Units: dB).

15. Center Frequency $($ CENTFREQ $)=$ Frequency that divides the selection into two frequency intervals of equal energy (Units: Hz).

16. Center Time $($ CENTTIME) $=$ Point in time at which the selection is divided into two time intervals of equal energy (Units: seconds).

17. Energy $($ ENERGY $)=$ The total energy within the selection bounds (Units: $\mathrm{dB}$ ).

18. IQR (Inter-quartile range) Bandwidth (IQRBW) = Difference between the 1st and 3rd Quartile Frequencies (Units: $\mathrm{Hz}$ ).

19. IQR (Inter-quartile Range) Duration (IQRDUR) = Difference between the 1st and 3rd Quartile Times (Units: seconds).

20. Length of Spectrogram (LSPECT) $=$ The number of frames contained in a selection. For spectrogram and spectrogram slice views, the number of frames equals the number of individual spectra in the selection in one channel (Units : frames).

21. Maximum Frequency $($ MAXFREQ $)=$ Frequency at which max power occurs within the selection (Units: $\mathrm{Hz}$ ).

22. Maximum Power/Peak Power (MAXPOW) = Maximum power in the selection (Units: $\mathrm{dB}$ ).

23. Maximum Power Time $($ MAXPOWT) $=$ First time in the selection at which a sample with power equal to Max Power occurs (Units: seconds).

24. Maximum Frequency Time $($ MAXFREQT $)=$ First time in the selection at which a sample with power equal to Max Frequency occurs (Units: seconds).

\section{Data Analysis}

Prior statistical analyzes were performed, each value of the variable to be corrected for ewe. PROC GLM of SAS software Ver. 9.0 was used to obtain the value of the correction factor for sex. The least square means (LSM) on the results of analysis of variance was used to determine a correction factor. The correction factor for the sexes was calculated by adding or subtracting LSM of data.

Normal distribution test was conducted by the Kolmogorov-Smirnov test. Analysis of variance of each variable voice was performed using SAS software Ver. 9.0 with PROC GLM, and performed significance test 
to see the difference between the breeds of sheep. Model of linear equations used were:

$$
Y_{i j}=\mu+B_{i}+\varepsilon_{i j}
$$

which is:

$\mathrm{Y}_{\mathrm{ij}}=$ The observation of the i-th breed

$\mathrm{j}$-th $=$ Replication

$\mu \quad=$ The population mean

$\mathrm{B}_{\mathrm{i}}=$ The effect of the $\mathrm{i}$-th breed $(\mathrm{i}=1,2,3,4,5)$

$\varepsilon_{\mathrm{ij}}=\mathrm{A}$ random error due to the effect of the $\mathrm{i}$-th breed and the $\mathrm{j}$-th replication

PROC CANDISC of SAS software ver 9.0 used to perform the canonical discriminant analysis to calculate the Mahalanobis distance, canonical coefficients and provides a visual interpretation of differences in breeds of sheep. Based on Mahalanobis distance matrices that have resulted from previous analysis, PROC CLUSTER with Average Linkage method (Unweight Pair-Group Method Using Arithmetic Averages, UPGMA) perform hierarchical clustering. From the resulting output was then made dendogram to five breeds of sheep with PROC TREE of SAS software ver 9.0 (SAS 2002).

\section{RESULT AND DISCUSSION}

\section{Variation Voice Characteristics}

The 24 variables voice characteristics of breeds of sheep that can be calculated using voice analysis software Raven Pro 1.3 was shown in Table 1. It can be seen that duration of sheep voice varied between 0.96 to 1.52 seconds. Duration of sheep voice of SC and KG were no different, but the both sheep were different with sheep BC, LG and KS.

SC sheep had a voice with maximum amplitude (29584.8 units) while the lowest was KS sheep (24162.3 units). Voice energy of LG sheep (102.3 dB), SC sheep $(101.4 \mathrm{~dB})$ and $\mathrm{KG}(99.9 \mathrm{~dB})$ were not significant different but higher than BC sheep $(97.1 \mathrm{~dB})$ that equal to KS sheep $(97.7 \mathrm{~dB})$. Power Maximum of voice of BC and KS sheep was lower than SC and LG sheep. Variable of amplitude, energy and power related to the strength or weakness of the sound produced from each breeds of sheep. Engeldal et al. (2013) have reported that the difference in amplitude, energy and power of the sound produced, in addition to genetically influenced was also influenced by the environment (social isolation). Voice amplitude of Bison was closely related to competitive ability of bull (quality, condition and motivation), and thus, can be a selection signal for male sexual performance. Wyman et al. (2008) on the results of his research on Bison reported that there was a positive relationship between the voice amplitude, good physical condition and motivation, otherwise there was a negative relationship between the voice amplitude and quality of bull (mating and reproductive success).

Frequency variable indicates the high and low tone of voice. The results showed that the maximum frequency of LG sheep (1202.5 Hz) equal to SC sheep $(1408.5 \mathrm{~Hz})$, but lower than KS sheep $(1800.6 \mathrm{~Hz})$ and BC sheep (1642.7 Hz). Shillito-Waser \& Hague (1980) also found and reported that there was a difference some voice parameter of high-pitched sound between Clunt Forest, Jakob, Dalesbred and Border Leicester sheep. Some specific voice in sheep that indistinguishable was low-pitched voice is usually generated by lamb and high-pitched voice usually produced by ewes and also as a protest or miserable / sad voice (Krause \& Ruxton 2002). Some researchers reported a negative correlation between voice frequency and body size. The results of the study were reported in the species of bats (Zhang et al. 2000) and birds (Brumm \& Naguib 2009; Martin et al. 2011) as well as between species (Fletcher 2010). Allometric relationship between the voice frequency and body size arises because of physical and energy constraints; animals cannot efficiently produce voice waves that are larger than the body size or the apparatus of their voice production (Bradbury \& Vehrencamp 1998). This is opens an opportunity of indirect selection on the production traits of body weight by utilizing the voice frequency data.

The ability to produce voice depends on the existence of special elements of trachea; in mammals; pharyngeal cavity. Anatomy and function of the acoustic element determines the range, the acoustic characteristics and limits of voice production within species (Manteuffel et al. 2004). Changes that occur in an animal may be as a behavior reaction and or physiology that can be measured and used to describe the state of individual and the specific meaning of the voice. This makes the sound produced was useful as a tool to assess the status of well-being and stress on the individual animal (Weary \& Fraser 1995).

Visualize the sound of five sheep in the two forms of picture shown in Figure 1. The first visualization was in a waveform (top) and the second was a spectrogram (bottom). Waveform shape is visually describing voice in amplitude (vertical axis) versus time (horizontal axis). Meanwhile, visualization in a spectrograms describe voice in a frequency (vertical axis) versus time (horizontal axis) and power relatively at any point frequency and time indicated by the color of white, gray to black. The darker of dot indicate that power was getting stronger, so the darkest point was representing a maximum power in the voice. Visually difference in the five sheeps is shown in Figure 1. 
Table 1. Least square means of some waveform and spectrogram variables of voice from Barbados Black Belly Cross (BC), Local Garut (LG), Composite Garut (KG), Composite Sumatera (KS) and St. Croix (SC) sheep

\begin{tabular}{|c|c|c|c|c|c|}
\hline \multirow{2}{*}{ Variables } & \multicolumn{5}{|c|}{ Breed of Sheep } \\
\hline & SC & BC & LG & KG & $\mathrm{KS}$ \\
\hline DELTIME (second) & $1.15 \pm 0.06^{\mathrm{b}}$ & $0.92 \pm 0.06^{\mathrm{c}}$ & $1.52 \pm 0.06^{\mathrm{a}}$ & $1.13 \pm 0.05^{\mathrm{b}}$ & $0.96 \pm 0.05^{\mathrm{c}}$ \\
\hline LWAVE (frame) & $36270.70 \pm 1748.84^{b}$ & $29332.09 \pm 1748.84^{c}$ & $48251.90 \pm 1748.84^{\mathrm{a}}$ & $36098.80 \pm 1704.56^{\mathrm{b}}$ & $30558.41 \pm 1663.48^{c}$ \\
\hline MAXAMPT (second) & $0.36 \pm 0.03^{\mathrm{b}}$ & $0.47 \pm 0.03^{\mathrm{a}}$ & $0.52 \pm 0.03^{\mathrm{a}}$ & $0.48 \pm 0.03^{\mathrm{a}}$ & $0.35 \pm 0.03^{\mathrm{b}}$ \\
\hline MINAMP (unit) & $28998.03 \pm 1339.35^{\mathrm{b}}$ & $24910.87 \pm 1339.35^{\mathrm{a}}$ & $29161.82 \pm 1339.35^{b}$ & $27022.66 \pm 1305.44^{\mathrm{ab}}$ & $24010.97 \pm 1273.97^{a}$ \\
\hline MINAMPT (second) & $0.39 \pm 0.04^{\mathrm{ab}}$ & $0.46 \pm 0.04^{\mathrm{bc}}$ & $0.55 \pm 0.04^{\mathrm{cd}}$ & $0.47 \pm 0.04^{\mathrm{bcd}}$ & $0.36 \pm 0.03^{\mathrm{a}}$ \\
\hline PAMP (unit) & $30145.85 \pm 1327.002^{\mathrm{a}}$ & $26431.83 \pm 1327.002^{\mathrm{ab}}$ & $29742.96 \pm 1327.002^{\mathrm{a}}$ & $27719.09 \pm 1293.40^{\mathrm{ab}}$ & $24846.21 \pm 1262.23^{b}$ \\
\hline PAMPT (second) & $0.37 \pm 0.03^{\mathrm{c}}$ & $0.47 \pm 0.03^{\mathrm{b}}$ & $0.56 \pm 0.03^{\mathrm{a}}$ & $0.48 \pm 0.03^{\mathrm{b}}$ & $0.35 \pm 0.03^{\mathrm{c}}$ \\
\hline RMSAMP (unit) & $7206.82 \pm 386.86^{\mathrm{a}}$ & $5229.33 \pm 386.86^{\mathrm{b}}$ & $7529.58 \pm 386.86^{\mathrm{a}}$ & $6077.97 \pm 377.07^{\mathrm{b}}$ & $5444.41 \pm 367.98^{\mathrm{b}}$ \\
\hline Q1FREQ (Hz) & $986.61 \pm 60.67^{\mathrm{bc}}$ & $1169.72 \pm 60.67^{\mathrm{a}}$ & $867.83 \pm 60.67^{\mathrm{c}}$ & $1099.10 \pm 59.14^{\mathrm{ab}}$ & $1249.48 \pm 57.71^{\mathrm{a}}$ \\
\hline Q1TIME (second) & $0.33 \pm 0.02^{\mathrm{b}}$ & $0.36 \pm 0.02^{\mathrm{b}}$ & $0.42 \pm 0.02^{\mathrm{a}}$ & $0.35 \pm 0.02^{\mathrm{b}}$ & $0.28 \pm 0.02^{\mathrm{c}}$ \\
\hline Q3FREQ (Hz) & $1908.07 \pm 66.70^{\mathrm{b}}$ & $2441.25 \pm 66.70^{\mathrm{a}}$ & $1824.96 \pm 66.70^{\mathrm{ab}}$ & $1969.11 \pm 65.01^{\mathrm{b}}$ & $2304.66 \pm 63.44^{\mathrm{a}}$ \\
\hline Q3TIME (second) & $0.72 \pm 0.04^{\mathrm{bc}}$ & $0.63 \pm 0.04^{\mathrm{ab}}$ & $0.96 \pm 0.04^{\mathrm{d}}$ & $0.73 \pm 0.04^{c}$ & $0.57 \pm 0.04^{\mathrm{a}}$ \\
\hline AVGPOW & $79.88 \pm 0.86^{\mathrm{a}}$ & $76.56 \pm 0.86^{\mathrm{b}}$ & $79.65 \pm 0.86^{\mathrm{a}}$ & $78.25 \pm 0.84^{\mathrm{ab}}$ & $76.82 \pm 0.82^{\mathrm{b}}$ \\
\hline CENTFREQ (Hz) & $1492.37 \pm 64.26^{b c}$ & $1875.38 \pm 64.26^{\mathrm{a}}$ & $1360.77 \pm 64.26^{\mathrm{c}}$ & $1601.79 \pm 62.63^{b}$ & $1872.44 \pm 61.12^{\mathrm{a}}$ \\
\hline CENTTIME (second) & $0.51 \pm 0.03^{\mathrm{b}}$ & $0.48 \pm 0.03^{\mathrm{bc}}$ & $0.66 \pm 0.03^{\mathrm{a}}$ & $0.55 \pm 0.03^{\mathrm{b}}$ & $0.41 \pm 0.03^{\mathrm{c}}$ \\
\hline IQRBW (Hz) & $921.48 \pm 64.25^{\mathrm{b}}$ & $1271.55 \pm 64.25^{\mathrm{a}}$ & $957.12 \pm 64.25^{\mathrm{b}}$ & $812.35 \pm 62.62^{b}$ & $995.37 \pm 61.11^{\mathrm{b}}$ \\
\hline IQRDUR (second) & $0.41 \pm 0.03^{\mathrm{b}}$ & $0.31 \pm 0.03^{\mathrm{c}}$ & $0.56 \pm 0.03^{\mathrm{a}}$ & $0.41 \pm 0.03^{\mathrm{b}}$ & $0.31 \pm 0.03^{c}$ \\
\hline LSPECT (frame) & $282.25 \pm 13.44^{\mathrm{b}}$ & $229.21 \pm 13.44^{\mathrm{c}}$ & $376.93 \pm 13.44^{\mathrm{a}}$ & $287.02 \pm 13.10^{\mathrm{b}}$ & $239.92 \pm 12.79^{c}$ \\
\hline MAXFREQ (Hz) & $1408.45 \pm 82.51^{\mathrm{ab}}$ & $1642.69 \pm 82.51^{\mathrm{cd}}$ & $1202.48 \pm 82.51^{\mathrm{a}}$ & $1540.55 \pm 80.42^{\mathrm{bc}}$ & $1800.62 \pm 78.48^{\mathrm{d}}$ \\
\hline MAXPOW (dB) & $101.96 \pm 0.82^{\mathrm{a}}$ & $99.25 \pm 0.82^{\mathrm{b}}$ & $101.91 \pm 0.82^{\mathrm{a}}$ & $100.96 \pm 0.80^{\mathrm{ab}}$ & $98.78 \pm 0.78^{\mathrm{b}}$ \\
\hline MAXPOWT (second) & $0.43 \pm 0.04^{\mathrm{bc}}$ & $0.46 \pm 0.04^{\mathrm{bc}}$ & $0.57 \pm 0.04^{\mathrm{a}}$ & $0.51 \pm 0.04^{\mathrm{ab}}$ & $0.39 \pm 0.04^{c}$ \\
\hline MAXFREQT (second) & $0.43 \pm 0.04^{\mathrm{bc}}$ & $0.46 \pm 0.04^{\mathrm{bc}}$ & $0.58 \pm 0.04^{\mathrm{a}}$ & $0.51 \pm 0.04^{\mathrm{ab}}$ & $0.38 \pm 0.04^{c}$ \\
\hline
\end{tabular}

Different small letters on the same line showed significant differences $(\mathrm{P}<0.05)$

DELTIME = Delta Time LWAVE = Length of Waveform

MINAMP $=$ Minimum Amplitude $\quad$ MINAMPT $=$ Minimum Amplitude Time

$\begin{array}{ll}\text { RMSAMP }=\text { RMS Amplitude } & \text { Q1FREQ }=1 \text { st Quartile Frequency } \\ \text { Q3TIME }=3 \text { rd Quartile Time } & \text { AVGPOW }=\text { Average Power }\end{array}$

ENERGY $=$ ENERGY

MAXAMP $=$ Maximum Amplitude

PAMP $=$ Peak Amplitude

MAXAMPT = Maximum Amplitude Time

CENTFREQ $=$ Center Frequency
C

PAMPT $=$ Peak Amplitude Time

Q3FREQ $=3$ rd Quartile Frequency

$\mathrm{IQRBW}=\mathrm{IQR}$ (Inter-quartile range) Bandwidth $\mathrm{IQRDUR}=\mathrm{IQR}$ (Inter-quartile Range) Duration LSPEC $\quad \begin{aligned} & =\text { Length of Spectrogram } \\ & \text { L }\end{aligned}$

MAXFREQ $=$ Maximum Frequency $\quad$ MAXPOW = Maximum Power/Peak Power MAXPOWT = Maximum Power Time

MAXFREQT $=$ Length of Spectrogram
Maximum Frequency Time 
Table 2 shows a correlation between explanatory variables of voice characteristics and canonical discriminant function. The higher of correlation value indicates that the variable is closely associated with the differences in breeds of sheep. Based on the analysis of canonical structure variables for voice characteristics, there are several major variables that a key differentiator for breeds of sheep. Variables as a differentiator for sheep was Q3FREQ, CENTFREQ, and MAXFREQ (canonical 1) with a value of 0.700361 ,
0.670637 and 0.526933 respectively and Q1TIME (canonical 2) with a value of 0.515125 (Table 2). The differentiator variables are a variables related to the frequency of voice that indicates high or low tone of voice. It shows that the five breeds of sheep were observed can be distinguished based on the high and low tone of the voice produced, as has also been discovered and reported by Shillito-Waser and Hague (1980), his work for Clunt Forest, Jakob, Dalesbred and Border Leicester sheep.

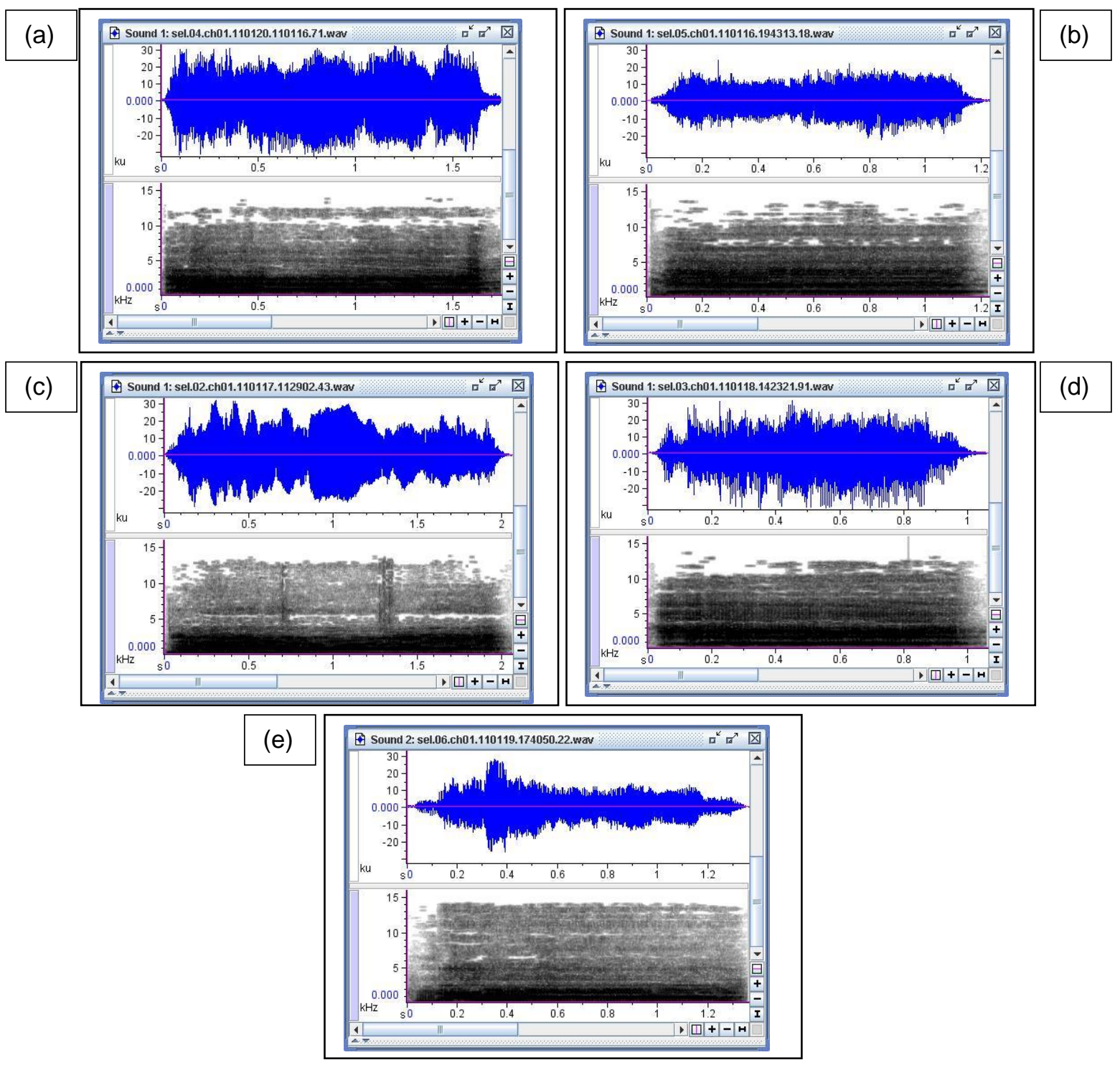

Figure 1. Sample of waveform (top) and spectrogram (below) image for St. Croix Cross (a), Barbados Black Belly Cross (b), Local Garut (c), Composite Garut (d) and Composite Sumatra (e) sheep 
Table 2. Structure of canonical for voice characteristics variables of Barbados Black Belly Cross (BC), Local Garut (LG), Composite Garut (KG), Composite Sumatra (KS) and St. Croix Cross (SC) sheep

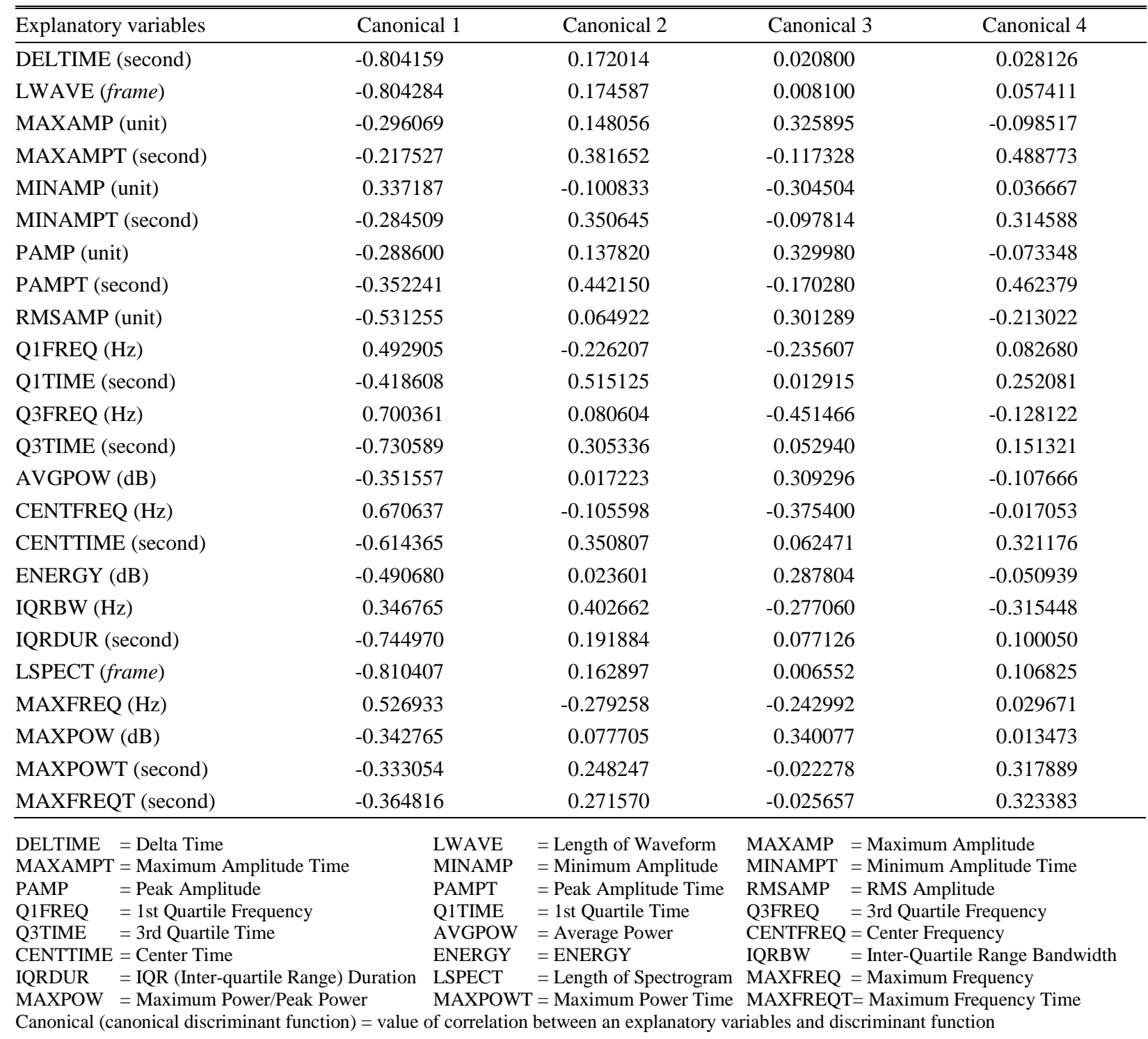

\section{Differentiation of sheep based on voice characteristics}

Plotting canonical shows graphically the grouping breeds of sheep was shown in Figure 2. Based on the canonical plotting voice characteristics, LG, KS and BC sheep were different groups of breed, while SC, KG and $\mathrm{KS}$ sheep were the one group sheep (visible coinciding on Figure 2). It means that SC, KG and KS sheep were in one group so has the voice characteristic relatively similar. However, the LG, KS and BC sheep have the different voice characteristics and it relates to the genetic similarity among sheeps. Differences between breeds of sheep in particular were at variable of frequencies, as shown in Table 2.
Mahalanobis distance values among the five sheeps observed were listed in Table 3. Based on the characteristics of voice, the closest genetic distance among of sheep was between SC and KG sheep with a value of 4.06042 and the probability distance was not significant $(\mathrm{P}>0.05)$. This means that the genetic distance of the two clusters of sheep are very close so it is not a separate sheep. The breed sheep that has a value closest genetic distance with the two breeds of sheep (KG and SC) were KS sheep, the closeness of three sheeps was also demonstrated by coinciding plotting in Figure 2. The closeness and relationship of three breeds because each breeds of sheep genetically have genes from a St. Croix sheep, meanwhile the farthest genetic 
Canonical 2

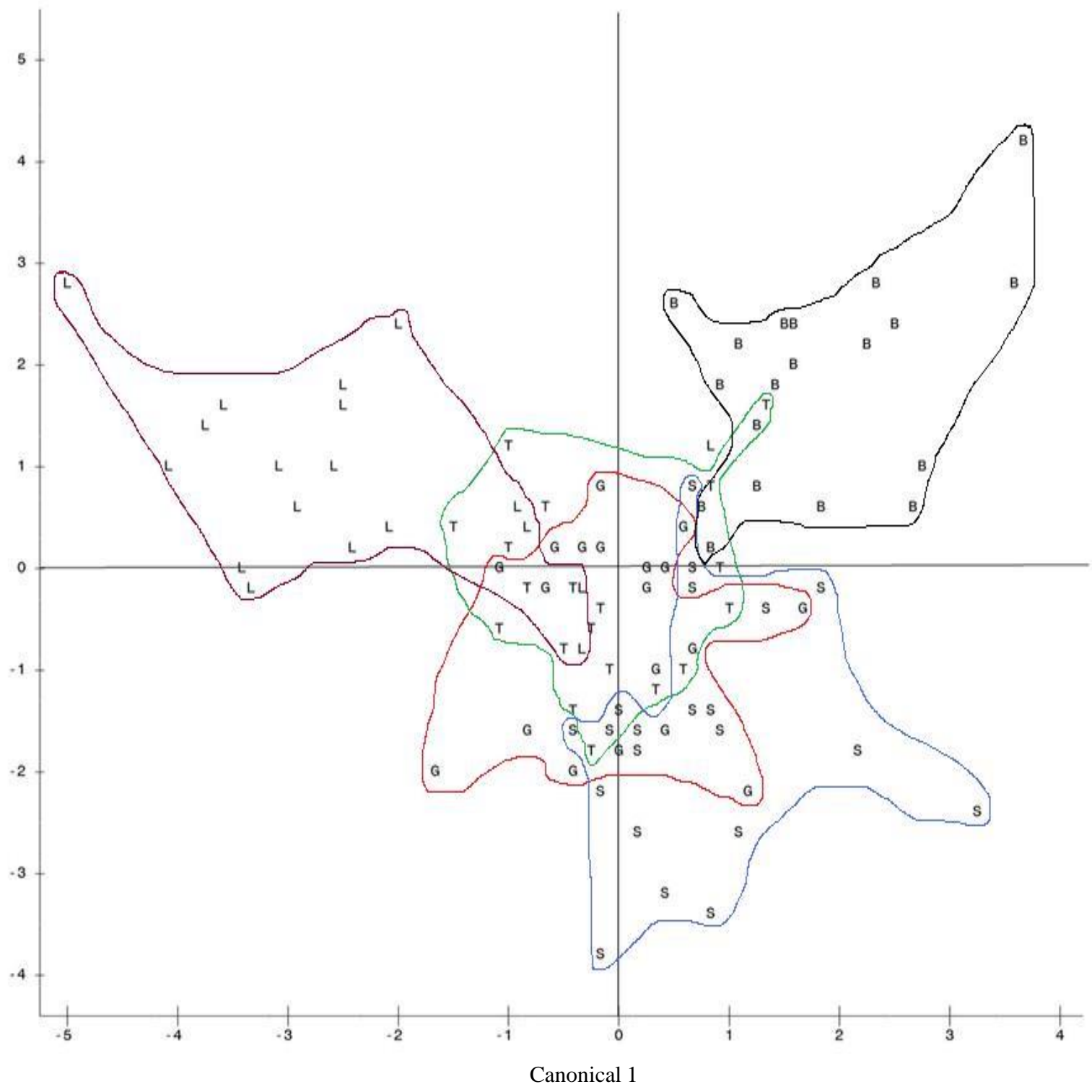

Figure 2. Plotting canonical illustrates grouping five breeds of sheep by the voice character (symbol letters $B=B C, L=L G, G=K G$, $\mathrm{S}=\mathrm{KS}, \mathrm{T}=\mathrm{SC}$ )

Table 3. Mahalanobis distance value and significance probabilities between five breeds of sheep

\begin{tabular}{lccccc}
\hline Breed of sheep & BC & KG & LG & KS & SC \\
\hline BC & 0 & 11.02691 & 18.27899 & 13.60458 & 11.27703 \\
KG & $<.0001$ & 0 & 10.07305 & 5.45791 & 4.06042 \\
LG & $<.0001$ & 0.0001 & 0 & 15.81412 & 10.31253 \\
KS & $<.0001$ & 0.0364 & $<.0001$ & 0 & 7.93047 \\
SC & $<.0001$ & 0.2399 & 0.0001 & 0.0017 & 0 \\
\hline
\end{tabular}

Values above the diagonal shows the value of Mahalanobis distance

Values below the diagonal indicate significance probability of Mahalanobis distance 
Barbados Blackbelly Cross

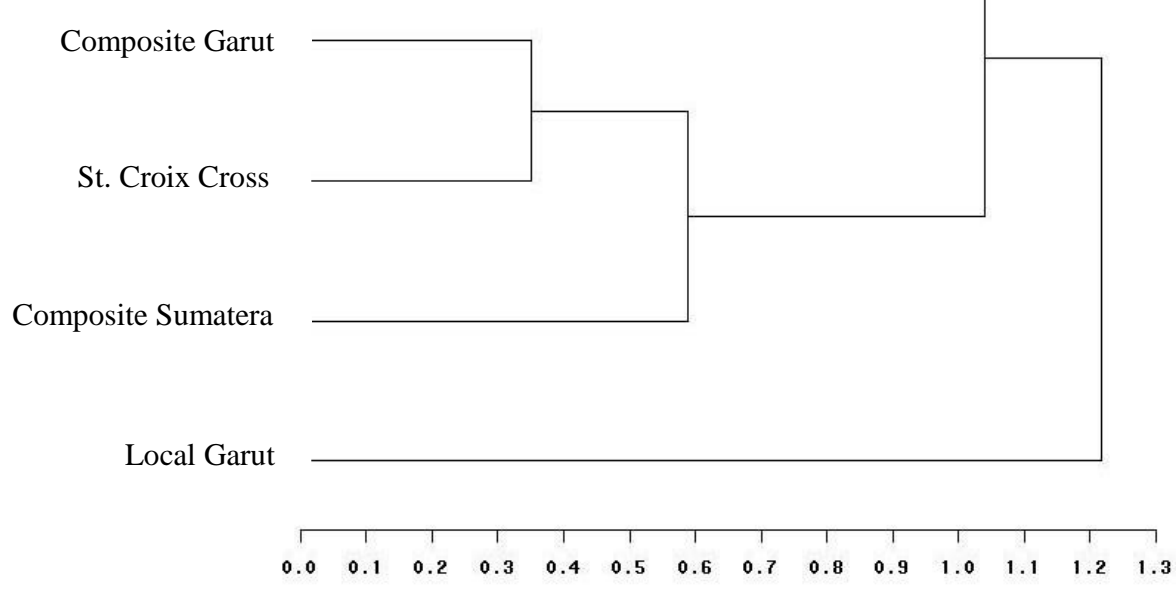

(a)

Barbados Blackbelly Cross

\author{
Barbados Blackbelly Cross
}

Composite Garut

St. Croix Cross

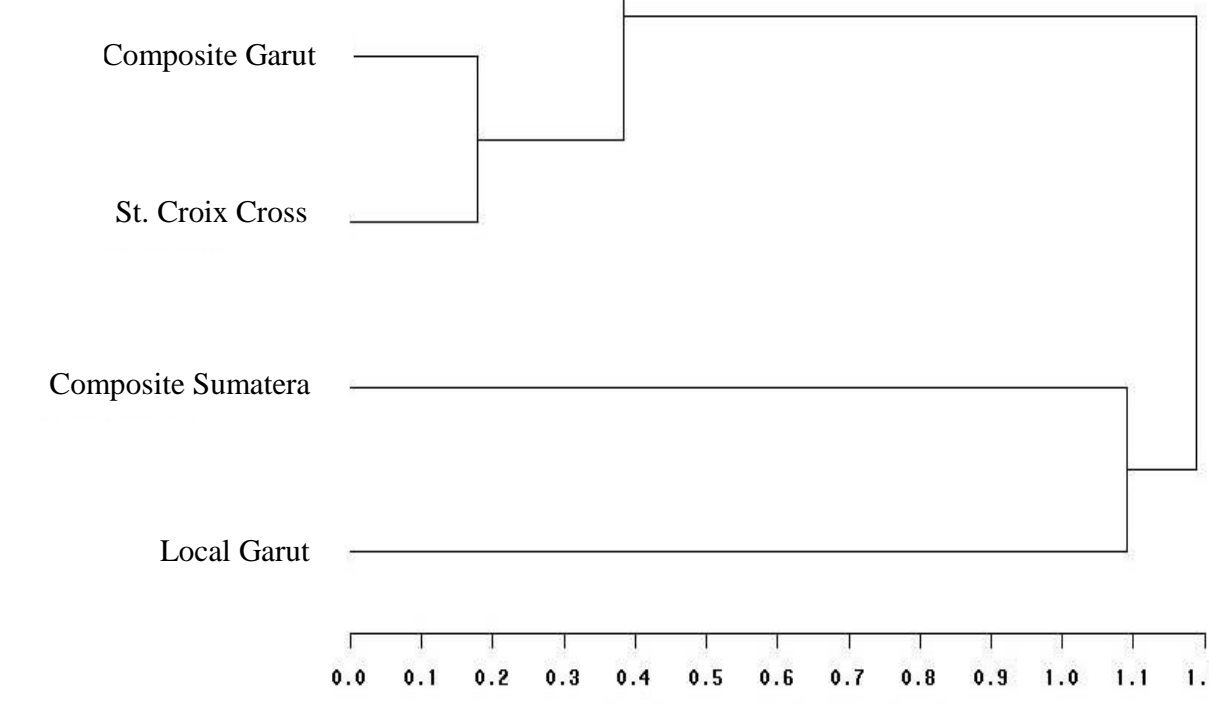

(b)

Figure 3. Comparison of dendrogram constructed based on the Mahalanobis distance of five sheeps based on data from the voice characteristics (a) and which have been reported by Handiwirawan et al. (2012) based on the body size (b)

distance shown between BC and LG sheep, with a value of 18.27899. This is because the two of sheeps (BC and LG sheep) have no common ancestor so they were not related genetically.

A dendogram (Figure 3) were made to clarify the relationship between the groupings of the five breeds of sheep by Mahalanobis distances were shown in Table 3. In the dendogram seen that KG and SC sheep were a group sheep with the closest genetic distance. The two of sheeps (KG and SC) were closer to KS sheep than the BC sheep. Nevertheless the four breeds of sheep
(KG, SC, KS, and BC) have close genetic distance and have a farther genetic distance with LG sheep.

In previous studies have reported the genetic distance between the five breeds of sheep by the body size; has showed genetic relationships accurately and high suitability in explaining among the five breeds of sheep (Handiwirawan et al. 2012). Comparison of dendogram built based on the characteristics of voice and body size seen in Figure 3. Position KG sheep was difference between dendogram made by voice characteristics compared dendogram made based on the 
body size. Unlike the dendogram built from voice characteristics, based on body size KG sheep has the genetic distance that is closer to the sheep LG and form a separate group with a group of sheep KS, SC and BC.

As described in previous studies by Handiwirawan et al. (2012) although the common ancestor for KS and KG sheep were SC sheep, but the population of SC sheep as common ancestor for KS and KG sheep were a different population. The population of SC sheep as common ancestor for KS sheep was a crossbreed between St. Croix sheep and Local Sumatra sheep, while the population of SC sheep who become common ancestor for KG sheep was a crossbreed between St. Croix sheep and Local Garut sheep. The difference results of Mahalanobis distance values and dendogram showed that environmental factors provide a more powerful influence on the voice characteristics than body size. Voice characteristic was more labile than morphological traits (Mahler \& Gil 2009) so that the influences of surrounding environment against voice variables chances were pretty high that caused the differences in results between the two methods. Some environmental effects have been identified affect the characteristics of the voice produced. It has been reported that social isolation and stress environment affect the characteristics of the voice emitted sheep and goats (Engeldal et al. 2013; Siebert et al. 2011). Taylor \& Reby (2010) have found that fluctuations in the emotional or motivational physiology affect the voice characteristics. Results of research on birds found that environmental factors that affect the voice was habitat structure, source of noise and weather conditions (Brumm \& Naguib 2009). Environmental influences that are not able to be eliminated in this study were the possibility of communication between the sheep that are likely to affect the voice characteristics. Naturally, sheep was a type of livestock that have a congregate character, do not like to be alone. Sampling the voice of sheep in the study was collected by separating the sheep from the group in a separate enclosure so the sheep produced voice for their inconvenience. Nonetheless, communication can still be done by sheep samples that can be done with a combination of visual, auditory and olfactory/chemical transmission except for physical contact.

Nevertheless, the results of voice characteristics analysis showed only slight differences compared with the results of body size analysis, so that this method has a good chance to be applied. If the environmental factors of considerable influence can be eliminated, this method is a method that has the advantage because of not needing to catch or touch the animals observed and easier in its undertaking. The usefulness of this method is great especially for application in wild animals or kept extensively.

\section{CONCLUSION}

Variables for the voice characteristic which can be used as a differentiator of sheep was related to the frequency of voice produced sheep, especially the third quartile frequency, center frequency, maximum frequency and the first quartile time. Dendogram built based on the Mahalanobis distance of voice characteristics put Composite Garut sheep in the group who was less accurate. Slight differences in the grouping of sheep shown from the analysis of voice and body size showed that the genetic distance estimation method using voice characteristics data have the opportunity to apply.

\section{REFERENCES}

Benz BW, Robbins MB. 2011. Molecular phylogenetics, vocalizations, and species limits in Celeus woodpeckers (Aves: Picidae). Mol Phylogenet Evol. 61:29-44.

Bradbury JW, Vehrencamp SL. 1998. Principles of animal communication. Sunderland (UK): Sinauer Associates.

Brumm H, Naguib M. 2009. Environmental acoustics and the evolution of bird song. In: Naguib M, Janik VM, Zuberbuhler K, Clayton NS, editors. Advances in the Study of Behaviour: Vocal Communication in Birds and Mammals. Vol. 40. London, Burlington, San Diego, Amsterdam: Elsevier Inc. p. 1-33.

Burton JA, Nietsch A. 2010. Geographical variation in duet songs of Sulawesi Tarsiers: Evidence for new cryptic species in South and Southeast Sulawesi. Int J Primatol 31:1123-1146. doi: 10.1007/s10764-010-9449-8.

Castellote M, Fossa F. 2006. Measuring acoustic activity as a method to evaluate welfare in captive Beluga Whales (Delphinapterus leucas). Aquatic Mammals 32:325-333. doi: 10.1578/AM.32.3.2006.325.

Charif RA, Waack AM, Strickman LM. 2008. Raven Pro 1.3 User's Manual. New York (USA): Cornell Laboratory of Ornithology, Ithaca.

Chesmore D. 2004. Automated bioacoustic identification of species. Ann Braz Acad Sci. 76:435-440.

Dere'gnaucourt S. 2010. Interspecific hybridization as a tool to understand vocal divergence: The example of crowing in quail (Genus Coturnix). PLoS ONE. 5:e9451. doi: 10.1371/journal.pone.0009451.

Engeldal SEC, Subandriyo, Handiwirawan E, Noor RR. 2013. Effect of different levels of social isolation on the acoustical characteristics of sheep vocalization. JITV. 18:208-219.

Esser D, Schehka S, Zimmermann E. 2008. Speciesspecificity in communication calls of tree shrews (Tupaia: Scandentia). J Mammal. 89:1456-1463. 
Ey E, Hammerschmidt K, Seyfarth RM, Fischer J. 2007. Ageand sex-related variations in clear calls of Papio ursinus. Int J Primatol. 28:947-960.

Fitch TW, Neubauer J, Herzel HP. 2002. Calls out of Chaos: The adaptive significance of nonlinear phenomena in mammalian vocal production. Anim Behav. 63:407-418.

Fletcher NH. 2010. A frequency scale rule in mammalian vocalization. In: Brudzynski SM, editor. Handbook of Mammalian Vocalization: An Integrative Neuroscience Approach. First Edition. London, Burlington, San Diego: Elsevier BV. p. 51-56.

Gogala M, Trilar T. 2004. Bioacoustic investigations and taxonomic considerations on the Cicadetta montana species complex (Homoptera: Cicadoidea: Tibicinidae). Ann Braz Acad Sci. 76:316-324.

Hall ML, Kingma SA, Peters A. 2013. Male songbird indicates body size with low-pitched advertising songs. PLoS ONE. 8:e56717. doi: 10.1371/journal.pone. 0056717.

Handiwirawan E, Noor RR, Sumantri C, Subandriyo. 2012 The differentiation of sheep breed based on the body measurements. J Indones Trop Anim Agric. 36:1-8.

Krause J, Ruxton GD. 2002. Living in group. New York (USA): Oxford University Press.

Lovell SF, Lein MR. 2013. Geographical variation in songs of a Suboscine Passerine, the Alder. The Wilson J Ornithol. 125:15-23.

Mahler B, Gil D. 2009. The evolution of song in the Phylloscopus Leaf Warblers (Aves: Sylviidae): a tale of sexual selection, habitat adaptation, and morphological constraints. In: Advances in the Study of Behaviour: Vocal Communication in Birds and Mammals. Vol. 40 Naguib M, et al., editors. London, Burlington, San Diego, Amsterdam: Elsevier Inc. p. 35-66.

Manteuffell G, Puppe B, Schon PC. 2004. Vocalization of farm animals as a measure of welfare. Appl Anim Behav Sci. 88: 163-182.

Martin JP, Doucet SM, Knox RC, Mennill DJ. 2011. Body size correlates negatively with the frequency of distress calls and songs of Neotropical birds. J Field Ornithol. 82:259-268. DOI: 10.1111/j.1557-9263.2011.00329.x.

Meen GH, Schellekens MA, Slegers MHM, Leenders NLG, van Erp-van der Kooij E, Noldus LPJJ. 2015. Sound analysis in dairy cattle vocalisation as a potential welfare monitor. Comput Electr Agric. 118:111-115.

Mena EEP, Mora EC. 2011. Geographic song variation in the non-oscine Cuban Tody (Todus multicolor). The Wilson J Ornithol. 123:76-84.

Ohya E. 2004. Identification of Tibicen cicada species by a principal components analysis of their songs. Ann Braz Acad Sci. 76:441-444.

Price T, Arnold K, Zuberbu“hler K, Semple S. 2009. Pyow but not hack calls of the male putty-nosed monkey (Cercopithcus nictitans) convey information about caller identity. Behaviour. 146:871-888.
Ranft R. 2004. Natural sound archives: Past, present and future. Ann Braz Acad Sci. 76:455-465.

Rheindt FE, Norman JA, Christidis L. 2008. DNA evidence shows vocalizations to be a better indicator of taxonomic limits than plumage patterns in Zimmerius tyrant-flycatchers. Mol Phylogenet Evol. 48:150-156.

Ruppell JC. 2010. Vocal diversity and taxonomy of Nomascus in Central Vietnam and Southern Laos. Int J Primatol. 31:73-94.

SAS. 2002. SAS/STAT User's guide release 9.0 edition. North Carolina (USA): SAS Institute Inc., Cary.

Schön PC, K Hämel, Puppe B, Tuchscherer A, Kanitz W, Manteuffel G. 2007. Altered vocalization rate during the estrous cycle in dairy cattle. J Dairy Sci. 90:202-206.

Scott G. 2005. Essential animal behavior. Victoria (Australia): Blackwell Publishing Ltd.

Sèbe F, Duboscq J, Aubin T, Ligout S, Poindron P. 2010. Early vocal recognition of mother by lambs: contribution of low- and high-frequency vocalizations. Anim Behav. 79:1055-1066.

Shillito-Waser EE, Hague P. 1980. Variation in the structure of bleats from sheep of four different breeds. Behaviour. 75:21-35.

Siebert K, Langbein J, Schon P, Tuchscherer A, Puppe B. 2011. Degree of social isolation affects behavioural and vocal response patterns in dwarf goats (Capra hirscus). J Appl Anim Behav Sci. 131:53-62.

Suzuki TN. 2014. Communication about predator type by a bird using discrete, graded and combinatorial variation in alarm calls. Anim Behav. 87:59-65.

Taylor AM, Reby D. 2010. The contribution of the sourcefilter theory to mammal vocal communication research. Mammal Vocal Communication and Cognition Research. Brighton (UK): School of Psychology, University of Sussex,

Vannoni E, McElligott AG. 2008. Low frequency groans indicate larger and more dominant fallow deer (Dama dama) males. PLoS ONE. 3:e3113.

Weary DM, Fraser D. 1995. Signalling need. Costly signals and animal welfare assessment. Appl Anim Behav Sci. 44:159-169.

Wyman MT, Mooring MS, Mc Cowan B, Cecilia M, Penedo T, Hart LA. 2008. Amplitude of bison bellows reflects male quality, physical condition and motivation. Anim Behav. 76:1625-1639. doi: 10.1016/j.anbehav.2008. 05.032.

Zhang SY, Zhao HH, Feng J, Sheng LX, Wang H, Wang LX. 2000. Relationship between echolocation frequency and body size in two species of hipposiderid bats. Chin Sci Bull. 45:1587-1590. 